(see GGU Reports of Activities for 1970 and 1971). It is hoped eventually to compile a new 1:10 000 map of that part of the instrusion situated to the south of Tunugdliarfik fjord.

S. A., J. B., S. K.-M., L. L., J. R.-H. \& H. S., Institut for Petrologi, University of Copenhagen, $\emptyset_{\text {stervoldgade 5-7, }}$ Copenhagen $K$.

\title{
PETROCHEMICAL WORK ON THE PRECAMBRIAN LAVAS, ERIKSFJORD FORMATION, SOUTH GREENLAND
}

\author{
Jørgen G. Larsen
}

The lavas of the Ilímaussaq Volcanic Member of the sandstone-volcanic Eriksfjord Formation (Stewart, 1964; Poulsen, 1964) can be subdivided into an upper Porphyry Division $(>600 \mathrm{~m}$ ) consisting mainly of trachytic rocks and a lower Basalt Division $(230-700 \mathrm{~m})$. To the south-west of the Ilímaussaq alkaline intrusion, the Basalt Division is markedly thinner (Stewart, 1964). During field work in 1970 samples of the volcanics were collected for petrochemical analysis. This report summarises the state of the subsequent laboratory work.

Forty-two major and trace element analyses have been made of the lavas. For norm calculation the $\mathrm{Fe}_{2} \mathrm{O}_{3} / \mathrm{FeO}$ ratios were corrected to 0.15 . There are no signs of fenitisation in the examined rocks except in those collected from close to the Ilimaussaq intrusion.

\section{The Basalt Division}

This comprises hypersthene-normative olivine basalts and hypersthene-normative hawaiites. These usually contain phenocrysts of plagioclase and pseudomorphed olivine. The plagioclase is generally slightly sericitised. When more extensively sericitised the lavas become nepheline-normative in accordance with Stewart's (1964) suggestions. Of the freshest lavas investigated, none are nepheline-normative. Although the hypersthene-normative content of some of these lavas is higher than in most basic rocks of the Gardar province, their mineralogy and trace element distribution are of alkaline affinity. The higher hypersthene norm may or may not be of primary origin - this will be discussed in a later publication. The highest $\mathrm{A}_{2} \mathrm{O}_{3}$ content recorded is $16.3 \%$ (plagioclase phenocrysts subtracted), being only found in the more primitive flows.

The chemical variation from olivine basalt to hawaiites can be explained by fractional crystallisation of the following normative composition (wt. $\%, 62 \%$ 
plagioclase (An 55*), 16\% olivine (Fo 59*), 8\% diopside, $7 \%$ hypersthene, $3 \%$ ilmenite, $2 \%$ magnetite and $3 \%$ orthoclase. This would be equivalent to an olivine gabbro with fairly low $\mathrm{P}_{2} \mathrm{O}_{5}$ content $(0-0.25 \%)$.

Plotting of the lavas in the CMAS system (O'Hara, 1968; Jamieson, 1969; modified by J. E. Engell, pers. comm.) indicates that the olivine basaltic liquid could have been in equilibrium with plagioclase, olivine, hypersthene and spinel at fairly low pressure. About $60 \%$ of the above-mentioned cumulate has to be subtracted from the more primitive magma to obtain the most differentiated hawaiites. The trace elements are in fair agreement with this model of evolution. The occurrence of hypersthene in the expected cumulate rock is believed not to be critical to this model as hypersthene-normative rocks without modal hypersthene or pigeonite are quite common, but hypersthene has in fact been found as inclusions in one early Gardar olivine dolerite dyke (Bridgwater \& Harry, 1968).

One flow in the Basalt Division with an almost ultramafic normative composition shows close chemical similarities to the pyroxenites of Narssaq and Tugtutôq described by Ussing (1912), Upton (1962) and Watt (1966).

\section{The Porphyry Division}

This is composed of slightly undersaturated trachyandesites, trachytes, phonolites and peralkaline trachytes and phonolites. More basic rocks also occur but these have not been investigated. As yet the peralkaline lavas have only been found in the lower part of the Porphyry Division where also a small outcrop of an acid pyroclastic occurs.

\section{References}

Bridgwater, D. \& Harry, W. T. 1968: Anorthosite xenoliths and plagioclase megacrysts in Precambrian intrusions of South Greenland. Bull. Grønlands geol. Unders. 77, 243 pp. (also Meddr Grønland 185, 2).

Jamieson, B. G. 1969: Natural rock projection into a pseudo-quaternary system. In Progress in Experimental Petrology, Nat. Environ. Res. Council, Publ. Ser. [D], 1, (2), 152-155.

O'Hara, M. J. 1968: The bearing of phase equilibria studies in synthetic and natural systems on the origin and evolution of basic and ultrabasic rocks. Earth-Sci. Rev. 4, 69-133.

Poulsen, V. 1964: The sandstones of the Precambrian Eriksfjord Formation in South Greenland. Rapp. Grønlands geol. Unders. 2, 16 pp.

Stewart, J. W. 1964: The earlier Gardar igneous rocks of the Ilímaussaq area, South Greenland. Unpublished Ph. D. thesis, Univ. of Durham. $423 \mathrm{pp}$.

Upton, B. G. J. 1962: Geology of Tugtutôq and neighbouring islands, South Greenland. Part 1. Bull. Grønlands geol. Unders. 34, 60 pp. (also Meddr Grønland 169, 8).

Ussing, N. V. 1912: Geology of the country around Julianehaab, Greenland. Meddr Grønland 38, $376 \mathrm{pp}$.

Watt, W. S. 1966: Chemical analyses from the Gardar Igneous Province, South Greenland. Rapp. Grønlands geol. Unders. 6, 92 pp.

Institut for Petrologi, University of Copenhagen,

Østervoldgade 5-7, 1350 Copenhagen $K$.

* molecule \% 